CLINICAL STUDY

\title{
Effect of DHEA-sulfate on adiponectin gene expression in adipose tissue from different fat depots in morbidly obese humans
}

Juan Jose Hernandez-Morante, Fermin Milagro ${ }^{1}$, Jose Antonio Gabaldon ${ }^{2}$, Jose Alfredo Martinez ${ }^{1}$, Salvador Zamora and Marta Garaulet

Department of Physiology, Faculty of Biology, University of Murcia, 30100 Murcia, Spain, ${ }^{1}$ Department of Physiology and Nutrition, University of Navarra, Pamplona. Spain and ${ }^{2}$ Technological Centre for the Canning and the Food Industry, Molina de Segura, Murcia, Spain

(Correspondence should be addressed to M Garaulet; Email: garaulet@um.es)

\begin{abstract}
Objective: A growing body of studies has demonstrated the inverse relationship between DHEA-sulfate (DHEA-S) and the pathological alterations associated with the metabolic syndrome. However, the mechanism by which DHEA-S treatment operates has not been elucidated completely. Adiponectin, an adipose-specific protein, is thought to have anti-diabetic and anti-atherosclerotic properties. Because fat depots differ in the impact of their relationship with the undesirable consequences of obesity, the aim of the present study was to investigate the effect of DHEA-S on adiponectin expression in both s.c. and visceral tissues in a morbidly obese population.

Design and methods: We studied the in vitro expression of the adiponectin gene from paired biopsies of human visceral and s.c. adipose tissue, obtained from men and women (body mass index $=48.68 \pm$ $7.43 \mathrm{~kg} / \mathrm{m}^{2}$ ). Adipocytes were incubated for $24 \mathrm{~h}$ with or without DHEA-S. Adiponectin mRNA was measured by reverse transcription-quantitative PCR.

Results: In this population, DHEA-S plasma values were $141 \pm 105 \mu \mathrm{g} / 100 \mathrm{ml}$. Serum adiponectin values were under normal ranges. In basal conditions, s.c. tissue expressed higher amounts (58\%) of adiponectin mRNA than visceral tissue $(P=0.027)$. Adiponectin expression was differentially regulated in the two depots by DHEA-S. There was a significant increase in adiponectin expression specifically in the visceral tissue $(P=0.020)$, but no significant effect of DHEA-S on the s.c. tissue $(P=0.738)$.

Conclusions: In the present study, for the first time in humans, we have shown that DHEA-S treatment is a strong upregulator of adiponectin gene expression in omental adipocytes, suggesting that the positive effects observed by DHEA-S treatment in humans suffering from metabolic syndrome could be exerted through overexpression of adiponectin in the visceral depot.
\end{abstract}

European Journal of Endocrinology 155 593-600

\section{Introduction}

The adrenal hormone DHEA and its sulfate derivative, DHEA-S, are secreted almost exclusively by the cortex of the adrenal gland. Although DHEA-S has few intrinsic androgenic actions, it is the major circulating steroid hormone in humans. DHEA can be converted by peripheral tissues, such as the gonads, skin, and adipose tissue (AT) into potent androgenic and estrogenic hormones, such as androstenedione, testosterone, estrone, and $17 \beta$-estradiol $(1,2)$.

A large number of studies have examined the inverse relationship between overweight, central obesity, and plasma levels of DHEA and DHEA-S (3, 4). Furthermore, several clinical trials have demonstrated that DHEA treatment reduces body fat (5) and increases lean body mass $(5,6)$. A high concentration of DHEA in cultures of preadipocytes has been reported to reduce the rate of differentiation of 3T3-L1 preadipocytes into mature, lipid-filled adipocytes by as much as $50 \%(7,8)$, and also decrease preadipocyte proliferation (9). However, the mechanism by which DHEA or DHEA-S treatment affect adiposity has not yet been determined.

Insulin resistance is often associated with increased body weight and obesity, with intra-abdominal obesity being more detrimental than peripheral obesity (10-12). It has been suggested that DHEA may be related to insulin resistance and hyperinsulinemia, and that this relationship could be a consequence of obesity. It has also been shown that reduced DHEA may directly contribute to insulin resistance by increasing insulin binding to its own receptor (13).

Various adipocyte-secreted proteins have been described that are altered in obesity and affect insulin sensitivity, and might, therefore, provide a link between these two pathological states. Among these 
adipocytokines, the product of the adipose most-abundant gene transcript 1 (apM1), adiponectin, appears to play an important role in carbohydrate and lipid metabolism (14).

Adiponectin is a potent insulin enhancer in mouse models of obesity, lipoathrophy and diabetes, and hypoadiponectinemia has been linked to insulin resistance in humans. Although adiponectin is secreted only from AT, its levels are paradoxically lower in obese than in lean humans (15). Body fat distribution has also been associated with plasma adiponectin levels and AT expression, this association being inverse with central obesity (16). This protein appears to be a major modulator of insulin action by enhancing insulinmediated suppression of hepatic glucose production (17). Moreover, plasma adiponectin levels in diabetic subjects with coronary artery disease (CAD) are lower than in diabetic patients without CAD, suggesting that adiponectin may have anti-atherogenic properties (18). The association of low adiponectin levels with obesity, insulin resistance, $\mathrm{CAD}$, and dyslipidemia indicates that this protein may be an important marker of the metabolic syndrome.

Thus, the aim of the present study was to determine the effect of DHEA-S treatment on adiponectin gene expression in human primary AT cultures from morbidly obese patients and to analyze a possible differential effect in two abdominal (s.c. and visceral) fat depots.

\section{Subjects and methods}

\section{Subjects}

Visceral and s.c. abdominal AT biopsies were obtained from a total of 25 Caucasians subjects (10 men and 15 women; mean age $42.8 \pm 10.2$ years) with morbid obesity (body mass index (BMI) $\geq 40 \mathrm{~kg} / \mathrm{m}^{2}$ ), from the General Surgery Service of 'Virgen de la Arrixaca' University Hospital, undergoing laparoscopic gastric bypass surgery due to obesity. After an overnight fast, the AT biopsies were taken as paired samples from the two AT depots at the beginning of the surgical procedure. Visceral AT was taken from the omental depot. The abdominal s.c. AT was taken $5 \mathrm{~cm}$ lateral from umbilicus. All biopsies were transported in sterile containers within $30 \mathrm{~min}$ of removal and were used in subsequent cultures.

The protocols were approved by the Ethics Committee of the 'Virgen de la Arrixaca' University Hospital, and the subjects gave written informed consent before the biopsies were obtained.

\section{Anthropometric measurements}

The evaluation of obesity was carried out according to the criteria proposed by the Spanish Society for the Study of Obesity (19). Weight was determined in subjects wearing light clothes and bare-footed, using a digital electronic weighing scale. Height was determined using a Harpenden digital stadiometer (range 0.70$2.05 \mathrm{~m}$ ), with the subject upright and the head in the Frankfurt plane. From these data, BMI was calculated.

Total body fat $(\%)$ was measured by bioimpedance with a TANITA Model TBF-300 (TANITA Corporation of America, Arlington Heights, IL, USA). Body fat distribution was assessed using waist circumference at the level of midway between the lower rib margin and the iliac crest, and hip, the widest circumference over the great trocanters. The waist-to-hip ratio was calculated from these measurements.

\section{Serum hormone determinations}

Blood samples were collected the day before surgery following an overnight fast. Serum was separated after centrifugation and stored at $-70^{\circ} \mathrm{C}$ until analyzed.

Insulin and sex hormone-binding globulin (SHBG) were determined by IRMA with reagents from Biosource (Fleurus, Belgium), and Orion Diagnostica (Espoo, Finland) respectively. The sensitivity of the method was $1 \mu \mathrm{U} / \mathrm{ml}$ for insulin and $0.5 \mathrm{nmol} / \mathrm{l}$ for SHBG. The intra-assay coefficient of variation $(\mathrm{CV})$ was $4.5 \%$ at a serum insulin concentration of $6.6 \mu \mathrm{U} / \mathrm{ml}$ and $2.1 \%$ at $53 \mu \mathrm{U} / \mathrm{ml}$; and $5.3 \%$ at a serum SHBG concentration of $17.7 \mathrm{nmol} / \mathrm{l}$ and $5.6 \%$ at $156.8 \mathrm{nmol} / \mathrm{l}$.

$17 \beta$-Estradiol and testosterone were determined by ELISA/competition with biotine/estreptavidine technology with reagents purchased from Boehringer Mannheim Immunodiagnostics (Meylan, France). Androstenedione and DHEA-S were determined by RIA with reagents purchased from Immunotech (Marseille, France), and Diagnostic Systems Laboratories, Inc. (Webster, TX, USA) respectively. The assays had sensitivities of $0.1 \mathrm{ng} / \mathrm{ml}$ for androstenedione and $1.7 \mu \mathrm{g} / 100 \mathrm{ml}$ for DHEA-S. The intra-assay CVs were $8.9 \%$ at a mean androstenedione concentration of $0.58 \mathrm{ng} / \mathrm{ml}$ and $4.1 \%$ at a mean value of $6.68 \mathrm{ng} / \mathrm{ml}$; $9.4 \%$ at a mean DHEA-S concentration of $20.3 \mu \mathrm{g} / 100 \mathrm{ml}$ and $6.3 \%$ at $593.3 \mu \mathrm{g} / 100 \mathrm{ml}$. The normal ranges according to the hospital standards were as follows: insulin, $5 \pm 25 \mu \mathrm{U} / \mathrm{ml} ; 17 \beta$-estradiol, $10 \pm$ $39 \mathrm{pg} / \mathrm{ml}$ in males and $10 \pm 147 \mathrm{pg} / \mathrm{ml}$ in females in the follicular phase; $110 \pm 338$ during menses; $27 \pm 247$ in the luteal phase; and $0.01 \pm 46$ in the postmenopausal state; androstenedione, $0.61 \pm 3.71 \mathrm{ng} / \mathrm{ml}$ in males and $0.46 \pm 3.39 \mathrm{ng} / \mathrm{ml}$ in females; testosterone, $2 \pm$ $8.5 \mathrm{pg} / \mathrm{ml}$ in males and $0.01 \pm 0.86 \mathrm{pg} / \mathrm{ml}$ in females; DHEA-S, $281 \pm 606 \mu \mathrm{g} / 100 \mathrm{ml}$ in males from 17 to 50 years and $195 \pm 507 \mu \mathrm{g} / 100 \mathrm{ml}$ in females; SHBG, $10 \pm 50 \mathrm{nmol} / \mathrm{l}$ in males and $30 \pm 90 \mathrm{nmol} / \mathrm{l}$ in females.

Plasma adiponectin concentrations were measured by ELISA being plasma samples diluted 500-fold with a buffer (Mediagnost, Reutlingen, Germany). The sensitivity of the method was $0.6 \mathrm{ng} / \mathrm{ml}$. The intra- and interassay CVs were less than 4.7 and $6.7 \%$ respectively. 
Serum glucose concentration was measured in duplicate by the glucose oxidase method. Fasting insulin resistance index (homeostasis model assessment (HOMA)) was calculated with the accepted formula (20):

$$
\begin{aligned}
\mathrm{HOMA}= & \text { fasting glucose }(\mathrm{mmol} / \mathrm{l}) \\
& \times \text { fasting insulin }(\mathrm{mIU} / \mathrm{l}) / 22.5 .
\end{aligned}
$$

\section{Human primary adipose tissue cultures}

After laparoscopy procedure, in each patient, paired AT samples were obtained from both fat depots (s.c. and visceral; 4-5 g). The AT was carefully dissected out from skin and vessels and cut into small pieces (average weight $10 \mathrm{mg}$ ), and all subsequent procedures were carried out under laminar airflow and under sterile conditions. All cultures were performed in duplicate. Explants were then placed at $37{ }^{\circ} \mathrm{C}$ for $24 \mathrm{~h}$ in a humidified atmosphere containing $7 \% \mathrm{CO}_{2}$ in $100 \mathrm{~mm}$ diameter dishes. AT (800-1000 mg) was placed in $5 \mathrm{ml}$ Dulbecco's modified Eagles medium (DMEM) supplemented with $10 \%$ fetal bovine serum. After $24 \mathrm{~h}$, the medium was replaced in every well. DHEA-S $(1 \mu \mathrm{M})$ was added in s.c. and visceral AT cultures, in order to determine possible regional differences in the effect of this hormone on adiponectin expression. Incubation was continued for $24 \mathrm{~h}$.

\section{Adipocyte isolation and fat-cell data determination}

Adipocytes were isolated by the method of Rodbell (21) with modifications. The s.c. and omental fat tissues were digested in DMEM containing $0.5 \mathrm{mg} / \mathrm{ml}$ type-II collagenase (Sigma) and 1\% BSA (Sigma) for 2030 min at $37{ }^{\circ} \mathrm{C}$ under constant shaking. The reaction was stopped by dilution in PBS and filtered on a silk screen in order to retain undigested explants; isolated adipocytes were separated from the stromal-vascular fraction by floatation. The floating packed cells were washed twice with PBS. From the isolated adipocytes, an aliquot was photographed under microscope using a digital camera connected to an image analyzer (MIP-Microm, Barcelona, Spain). Mean fat-cell diameter was determined by measuring the diameter of at least 200 cells.

The total fat-cell number was calculated by dividing the weight of total body fat by the average of the mean fat-cell weights of the two AT regions studied: s.c. and visceral (3).

\section{RNA extraction from isolated adipocytes}

After $24 \mathrm{~h}$ incubation, AT explants were digested as described earlier. Total RNA was extracted from isolated adipocytes using RNeasy Kit (Qiagen) according to the instructions of the company, except that the fat cake was removed by centrifugation before loading the purifying columns.

RNA was quantified by measuring absorbancy at 260 and $280 \mathrm{~nm}$. The integrity of the RNA was checked by visual inspection of the two rRNAs $18 \mathrm{~S}$ and $28 \mathrm{~S}$ on a $1 \%$ agarose gel.

\section{Real-time PCR measurement of adiponectin mRNA}

Reverse transcription (RT) was performed using random hexamers as primers and Thermoscript reverse transcriptase (Invitrogen) with $1 \mu \mathrm{g}$ total RNA for each sample.

Quantitative real-time PCR was performed using an ABI PRISM 7900 HT Sequence Detection System as described by the provider (Applied Biosystems, Foster City, CA, USA). PCR Master MIX (Perkin-Elmer, Norwalk, CT, USA) containing Hot Start Taq DNA polymerase. Taqman probes for human adiponectin and 18S rRNA as internal control were also supplied by Applied Biosystems (Assay-by-Design). All samples were determined as duplicates, and for a negative control the same setup was used except for the addition of RT. No PCR product was detected under these latter conditions. In brief, adiponectin mRNA and 18S RNA were amplified in separated wells at $95^{\circ} \mathrm{C}$ for $10 \mathrm{~min}$ and thereafter repeating cycles comprised $95^{\circ} \mathrm{C}$ for $30 \mathrm{~s}$ and $60{ }^{\circ} \mathrm{C}$ for $60 \mathrm{~s}$ for annealing and extension steps respectively. During the extension step, an increase in fluorescence was measured in real-time.

Relative quantities of transcript were calculated using the $2^{-\Delta \Delta C_{\mathrm{t}}}$ formula, where $C_{\mathrm{t}}$ is defined as the cycle number at which fluorescence is statistically significantly above background; $\Delta C_{\mathrm{t}}$ is the difference in $C_{\mathrm{t}}$ of the gene of adiponectin and $C_{\mathrm{t}}$ of $18 \mathrm{~S}$; and $\Delta \Delta C_{\mathrm{t}}$ is the difference in $\Delta C_{\mathrm{t}}$ of unknown sample and $\Delta C_{\mathrm{t}}$ of the calibrator/control sample (22). The results are expressed in arbitrary units with one unit being the mean mRNA levels determined in the control group. Amplification of specific transcripts was further confirmed by subjecting the amplification products to agarose gel electrophoresis.

\section{Statistical analysis}

Clinical and anthropometric data are presented as mean \pm s.e.m. The ranges of these results are also shown. Data for gene expression, expressed in arbitrary units, are also presented as mean \pm s.e.m.

Comparisons between men and women were analyzed by means of Student's t-test. To analyze the DHEA-S effect on adiponectin expression in s.c. and visceral depots, obtained from the same individual, we compared AT cultures without treatment, which was denominated 'control group', with the DHEA-S treated cultures, and we have expressed the adiponectin gene expression changes obtained by 
the DHEA-S effect by $n$-fold changes with respect to the control. The population was normally distributed; therefore, Student's paired t-test was used for comparing data from the samples derived from the two adipose depots in each individual subject, and to compare data from control (untreated) and DHEA-Streated samples. All statistical analyses were carried out using SPSS for windows (release 12.0; SPSS, Inc., Chicago, IL, USA).

\section{Results}

\section{General characteristics}

Table 1 contains several obesity parameters of the population studied $(n=25)$ and the characteristics of men $(n=10)$ and women $(n=15)$. BMI was higher than $40 \mathrm{~kg} / \mathrm{m}^{2}$, indicating that the patients studied suffered from morbid obesity. There were no significant differences in age or BMI between genders. The number of adipocytes was higher than $5 \times 10^{10}$, and with a size greater than $108 \mu \mathrm{m}$ diameter; therefore, the population studied showed hypertrophy and hyperplasia of adipocytes (23). The s.c. adipocyte diameter was significantly higher than visceral $(P=0.012)$ in the total population. Visceral diameter was significantly higher in men than in women $(P=0.020$; Table 1$)$.

Hormonal status and several glucose metabolism parameters of this population were also studied (Table 2). Significant differences were found between men and women. As expected, men presented higher DHEA-S and free testosterone values than their female counterparts $(P=0.025$ and 0.003 respectively). However, plasma adiponectin values were higher in women $(P=0.019)$.

As was expected, HOMA index of this morbidly obese population was elevated, in fact, HOMA was twice the normal range (3.8) (20). In the light of this result, we can define this population as insulin resistant.

\section{Basal adiponectin expression in samples from the two adipocyte depots}

Paired AT biopsies from the s.c. and the visceral depot were obtained from the laparoscopy obesity surgery. Adiponectin expression in the s.c. and visceral AT was measured after 24-h culture. Using group mean data, in basal conditions, the s.c. tissue expressed significantly higher amounts $(P=0.027)$ of adiponectin mRNA than visceral tissue (Fig. 1). In the s.c. tissue, adiponectin expression was $58 \%$ higher than in the omental.

When we compared the paired samples, this difference was still observed $(P=0.048)$. Data showed no significant differences between the genders in basal AT adiponectin gene expression in either s.c. AT $(P=0.655)$ or in the visceral depot $(P=0.199)$. Therefore, data were analyzed in the total population.

\section{Adiponectin expression response to DHEA-S from grouped samples from the two different depots}

Adiponectin expression was differentially regulated in the two depots by DHEA-S. Thus, at 24-h culture, there was a significant increase $(P=0.020)$ in adiponectin expression, specifically in the omental tissue, compared with the basal conditions (Fig. 2). In contrast, no significant effect of DHEA-S on the s.c. tissue was found $(P=0.738)$.

When the study was performed in the paired samples from each individual, the difference observed in the omental tissue compared with the basal condition still remained significant $(P=0.022$; paired $t$-test $)$. In this way, the s.c. adipocytes showed no significant differences $(P=0.529)$. Data show no significant differences between the genders in the adiponectin expression response to DHEA-S. Therefore, data were analyzed in the total population.

Table 1 General characteristics and fat-cell data of the total population studied.

\begin{tabular}{|c|c|c|c|c|}
\hline Clinical characteristics & Total population $(n=25)$ & Men $(n=10)$ & Women $(n=15)$ & $P$ \\
\hline Age (years) & $43 \pm 2(28-66)$ & $41 \pm 3(31-59)$ & $44 \pm 3(28-66)$ & 0.475 \\
\hline Weight (kg) & $133.6 \pm 5.1(95.9-202.3)$ & $156.2 \pm 6.4(133.8-202.3)$ & $118.6 \pm 4.1(95.9-160.0)$ & $<0.001$ \\
\hline Height (cm) & $165 \pm 2(150-190)$ & $173 \pm 3(161-190)$ & $159 \pm 2(150-173)$ & 0.001 \\
\hline BMI $\left(\mathrm{kg} / \mathrm{m}^{2}\right)$ & $48.7 \pm 1.5(37.0-70.0)$ & $51.9 \pm 2.7(37.3-70.0)$ & $46.5 \pm 1.5(37.0-59.4)$ & 0.073 \\
\hline$W C(\mathrm{~cm})$ & $140.9 \pm 4.1(104.5-179.6)$ & $155.8 \pm 4.4(141.7-179.6)$ & $131.0 \pm 4.7(104.5-167.3)$ & 0.001 \\
\hline WHR & $0.99 \pm 0.02(0.82-1.36)$ & $1.07 \pm 0.04(0.97-1.36)$ & $0.94 \pm 0.02(0.82-1.09)$ & 0.002 \\
\hline \%Fat & $46.6 \pm 1.5(24.5-56.7)$ & $40.9 \pm 2.6(24.5-53.5)$ & $50.3 \pm 1.0(43.5-56.7)$ & 0.005 \\
\hline Fat-cell number $\left(\times 1^{10}\right)$ & $9.29 \pm 0.59(4.08-14.91)$ & $8.12 \pm 0.93(4.08-11.78)$ & $10.14 \pm 0.69(6.12-14.91)$ & 0.094 \\
\hline Visceral adipocyte size $(\mu \mathrm{m})$ & $109 \pm 2(84-120)$ & $114 \pm 2(106-120)$ & $104 \pm 3(84-120)$ & 0.020 \\
\hline $\begin{array}{l}\text { Subcutaneous adipocyte } \\
\text { size }(\mu \mathrm{m})\end{array}$ & $116 \pm 2(90-135)$ & $120 \pm 3(109-135)$ & $112 \pm 3(90-127)$ & 0.085 \\
\hline
\end{tabular}

Data are presented as mean \pm S.E.M. (range). $P$ values were calculated using Student's $t$-test to compare men versus women. Significant differences $(P<0.05)$ are shown in bold. BMI, body mass index; WC, waist circumference; WHR, waist-to-hip ratio. 
Table 2 Hormonal status in the studied population.

\begin{tabular}{|c|c|c|c|c|}
\hline & Total population $(n=25)$ & Men $(n=10)$ & Women $(n=15)$ & $\boldsymbol{P}$ \\
\hline DHEA-S $(\mu \mathrm{g} / 100 \mathrm{ml})$ & $141 \pm 22(10-427)$ & $196 \pm 42(10-497)$ & $99 \pm 15(27-165)$ & 0.025 \\
\hline $17 \beta$-Estradiol $(\mathrm{pg} / \mathrm{ml})$ & $46 \pm 10(10-96)$ & $23 \pm 6(13-33)$ & $52 \pm 13(10-96)$ & 0.080 \\
\hline Free testosterone $(\mathrm{pg} / \mathrm{ml})$ & $6.7 \pm 1.9(0.2-31.9)$ & $13.9 \pm 3.1(3.2-31.9)$ & $1.2 \pm 0.3(0.2-3.7)$ & 0.003 \\
\hline SHBG $(\mathrm{nmol} / \mathrm{l})$ & $37 \pm 6(11-133)$ & $26 \pm 4(11-49)$ & $46 \pm 9(22-133)$ & 0.112 \\
\hline Androstenedione (ng/ml) & $1.4 \pm 0.1(0.3-3.0)$ & $1.5 \pm 0.2(0.8-2.3)$ & $1.4 \pm 0.2(0.3-3.0)$ & 0.744 \\
\hline Adiponectin $(\mu \mathrm{g} / \mathrm{ml})$ & $19.54 \pm 2.13(3.73-48.46)$ & $14.10 \pm 2.51(3.73-30.24)$ & $23.69 \pm 2.87(9.89-48-46)$ & 0.019 \\
\hline Insulin $(\mu \mathrm{U} / \mathrm{ml})$ & $27.3 \pm 4.1(5.7-80.2)$ & $23.7 \pm 5.3(6.2-50.0)$ & $29.8 \pm 6.1(5.7-80.2)$ & 0.487 \\
\hline Glucose (mg/dl) & $122.35 \pm 17.72(76.00-293.00)$ & $119.60 \pm 30.23(84.00-293.00)$ & $123.50 \pm 21.48(76.00-280.00)$ & 0.919 \\
\hline HOMA-IR & $7.00 \pm 1.07(2.60-15.82)$ & $6.35 \pm 2.54(3.42-15.82)$ & $7.32 \pm 0.97(2.60-9.99)$ & 0.664 \\
\hline C-peptide (ng/ml) & $4.4 \pm 0.6(1.4-14.2)$ & $5.0 \pm 1.4(3.4-14.2)$ & $4.1 \pm 0.4(1.4-6.6)$ & 0.467 \\
\hline
\end{tabular}

Data are presented as mean \pm S.E.M. (range). $P$ values were calculated using Student's $t$-test to compare men versus women. Significant differences $(P<0.05)$ are shown in bold. DHEA-S, dehydroepiandrosterone sulfate; SHBG, sex hormone-binding globulin; HOMA-IR, homeostasis-model assessment-insulin resistance.

\section{Discussion}

In the recent years, major advances include the recognition that AT is a highly secretory organ that releases a variety of factors, which can affect both insulin action and other functions (24). Also, it is well established that body fat distribution can affect some diseases related to adipose mass. The regional variations in adipocyte lipolytic responses and the differential expression of certain genes and secretory products have provided a framework from which to explore the differential impact of s.c. versus visceral AT on clinical risk $(25,26)$.

We have compared the in vitro adiponectin gene expression from adipocytes derived from two fat depots, s.c. and visceral in morbidly obese patients. Our results showed a statistically significant difference between the two compartments with a higher expression of adiponectin in s.c. human adipose culture versus

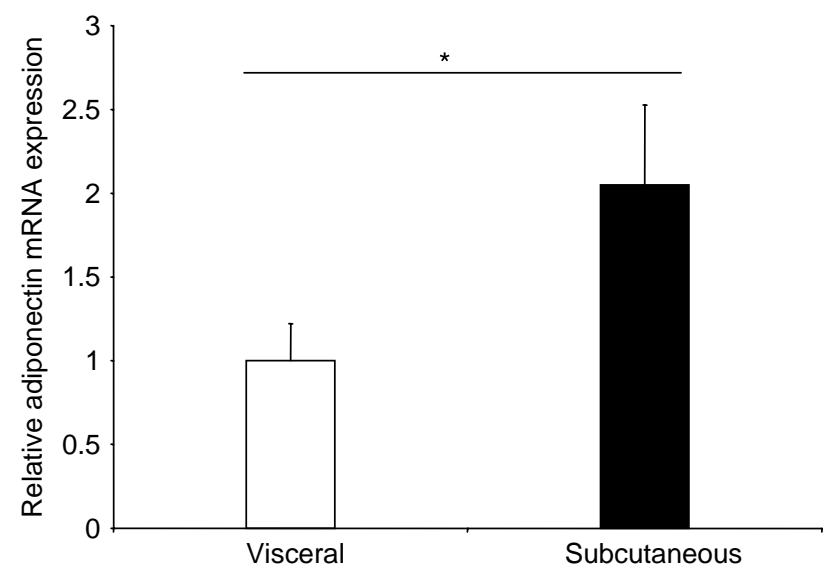

Figure 1 Adiponectin mRNA expression in the subcutaneous (black bar) and the omental (white bar) tissues in the basal state in the total population. Adiponectin mRNA level was measured with the realtime PCR and normalized to $18 \mathrm{~S}$ using the $\Delta \Delta \mathrm{C}_{\mathrm{t}}$ method of relative quantification. Data are reported as mean \pm S.E.M., and results are presented as percent of visceral group (visceral tissue value $=1$ ). ${ }^{\star} P<0.05$ (Student's $t$-test). visceral tissue (Fig. 1). These data are in disagreement with a study of Yang et al. (27) performed in obese women, who showed no depot difference in adiponectin mRNA levels. On the other hand, a study performed by Lihn et al. (28) showed significant differences in adiponectin gene expression only in lean women, but not in obese ones; whereas Fisher et al. (29) demonstrated a significantly lower adiponectin gene expression and protein content in omental AT compared
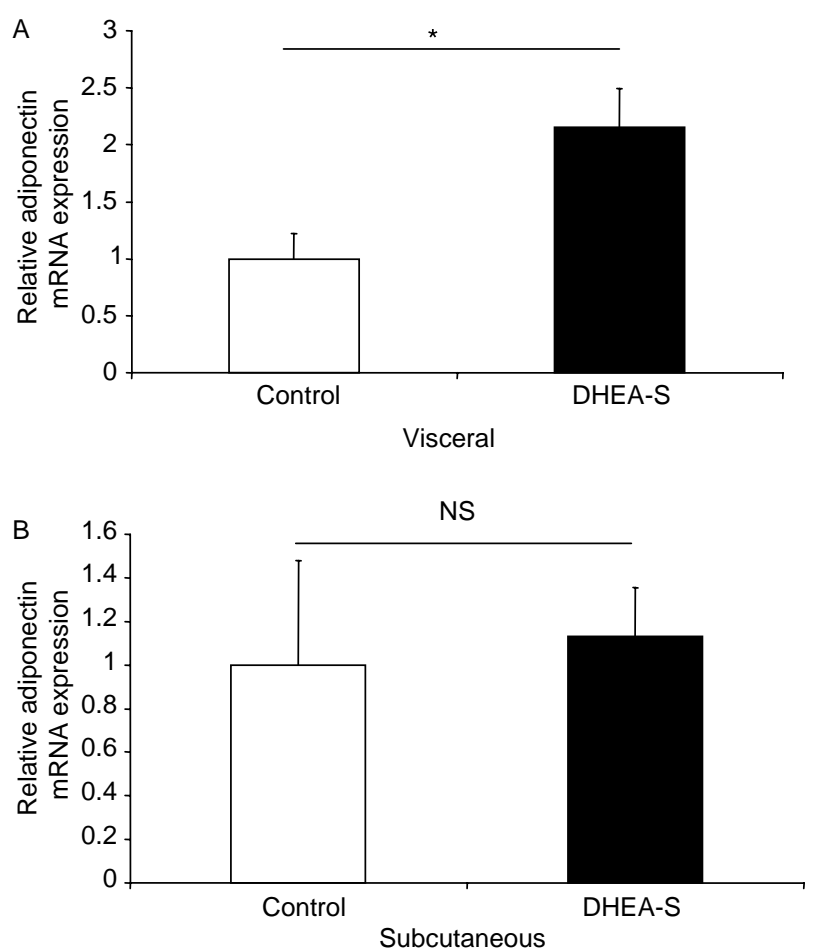

Figure 2 Differences in adiponectin gene expression between control and DHEA-sulfate-treated samples in (A) visceral and (B) subcutaneous adipose tissues. Adiponectin mRNA level was measured with the real-time PCR and normalized to $18 \mathrm{~S}$ using the $\Delta \Delta C_{t}$ method of relative quantitation. Data are reported as mean \pm S.E.M., and results are presented as percent of control group (control value $=1$ ). ${ }^{\star} P<0.05$ (Student's $t$-test). NS, no significant difference. 
with s.c. abdominal tissue. These apparent contradictory data could be due to differences in the general characteristics of the populations studied, i.e. BMI, age, body fat distribution, and hormonal status. Most of these studies in gene expression are carried out on AT obtained from dermolipectomies in very heterogeneous groups or in populations that are not well characterized. The present study was performed in a morbidly obese population, with a very high fat-cell size and number compared with the reviewed literature (23).

The hormonal status was also studied. Data showed higher plasma levels of insulin, androstendione, and SHBG, compared with the normal ranges according to the hospital standards, and lower DHEA-S plasma concentrations. These results confirm other studies performed in obese populations with similar serum hormone alterations (3). In concordance with previous results (15), in our population, women showed higher plasma adiponectin levels than men. In addition, circulating adiponectin values in these morbidly obese subjects were below data from normal weight populations reported in the reviewed literature, especially for men (30). These data could be influencing the insulinresistant state of this morbidly obese population. Indeed, the relationship between obesity and insulin resistance has been widely demonstrated (31). In this regard, in this morbidly obese population, both HOMA index and insulin values exceeded the normal range, which indicates that these morbidly obese patients could be classified as insulin-resistant subjects (20).

The main goal of the present study was to investigate the effect of a short-term DHEA-S incubation on human primary AT culture to elucidate the effect of this hormone on adiponectin gene expression. It has been shown previously that a decline in the circulating concentration of DHEA-S (the most abundant circulating steroid in humans) is linked to a number of disorders, including obesity and associated co-morbidities (insulin resistance, type- 2 diabetes, and atherosclerosis) $(3,32,33)$.

In this assay, we have observed that DHEA-S upregulates AT adiponectin gene expression in morbidly obese patients more than twofold (Fig. 2). This is the first study that demonstrates in humans the effect of DHEA-S in adiponectin gene expression in AT culture. A previous study by Karbowska et al. (34), who found a similar increase of adiponectin expression caused to DHEA treatment, was performed on rats.

The effect of DHEA-S on adiponectin expression was restricted to visceral AT in these morbidly obese patients. These results could be of interest in the treatment of morbid obesity taking into account the fact that visceral AT plays a major role in the pathogenesis of the metabolic syndrome (35).

The molecular aspects of DHEA or DHEA-S are still unclear (36). It has been postulated that DHEA-S could be related to adiponectin expression by its conversion to a more potent androgen, testosterone. However, this hormone has recently been shown to be a negative regulator of adiponectin production in humans (37). We have demonstrated a positive regulation of DHEA-S on adiponectin gene expression. Based on this evidence, it seems unlikely that DHEA-S exerted its effects via activation of androgen receptors.

Previous studies have revealed that DHEA-S acts as a peroxisome proliferator-activated receptor (PPAR) ligand (38). Indeed, PPAR $\gamma$ and DHEA have been related in the study of Karbowska et al. (34). On the other hand, Iwaki et al. (39) have identified a functional PPAR-responsive element in the promoter region of the gene-encoding adiponectin. Therefore, adiponectin expression and secretion are increased by activators of PPAR $\gamma(40)$. In this context, PPAR $\gamma$ could act as an important link between DHEA-S and adiponectin, and the adiponectin expression enhancement found in the human AT primary culture in the present study could be mediated by this transcription factor.

However, the analysis of the specific mechanism of action of DHEA-S, and the parallel influence on other genes, is limited in the present study because of the quantity of fat. The introduction of the laparoscopy techniques in the surgery process of morbid obesity has limited the accessibility to AT, specifically to the visceral depot.

Previous studies have shown that DHEA supplementation has beneficial effects on human diabetes and atherosclerosis (6), reporting a significant increase in insulin sensitivity in response to DHEA treatment. Also, it has been shown that adiponectin has anti-diabetic and anti-atherogenic properties (41). Thus, in the light of our results, we hypothesized that the beneficial effect of DHEA-S on atherosclerosis and diabetes observed in humans might be caused indirectly through an activation of adiponectin gene expression in visceral AT.

In conclusion, for the first time in humans, we have shown that DHEA-S treatment is a strong upregulator of adiponectin gene expression in primary AT culture, especially in the omental depot, suggesting that the observed positive effects of DHEA-S treatment in humans attending to the metabolic syndrome could be exerted indirectly by overexpression of adiponectin in the visceral fat depot.

\section{Acknowledgements}

The authors wish to thank P Gomez-Abellan, C Piernas and J A Jiménez-Bastida for their contributions and support, especially in the AT culture development. We also thank the staff from the General Surgery Service, 'Virgen de la Arrixaca' University Hospital, Murcia (Spain), especially to Dr Lujan, for their skilled technical assistance. We acknowledge the Institut Louis Bugnard, Unite Recherches sur les Obesites INSERM U586, Toulouse, France for the 1-year period in which Dr Garaulet improved gene expression techniques. 


\section{References}

1 Labrie F, Luu-The V, Labrie C \& Simard J. DHEA and its transformation into androgens and estrogens in peripheral target tissues: intracrinology. Frontiers in Neuroendocrinology 200122 185-212.

2 Killinger D, Strutt B, Roncari D \& Khalil W. Estrone formation from dehydroepiandrosterone in cultured human breast adipose stromal vascular cells. Journal of Steroid Biochemistry and Molecular Biology 199552 195-201.

3 Garaulet M, Perez-Llamas F, Fuente T, Zamora S \& Tebar FJ. Anthropometric, computed tomography and fat-cell data in an obese population: relationship with insulin, leptin, tumor necrosis factor-alpha, sex hormone-binding globulin and sex hormones. European Journal of Endocrinology 2000143 657-666.

4 Couillard C, Gagnon J, Bergeron J, Leon AS, Rao DC, Skinner JS, Wilmore JH, Despres JP \& Bouchard C. Contribution of body fatness and AT distribution to the age variation in plasma steroid hormone concentrations in men: the HERITAGE family study. Journal of Clinical Endocrinology and Metabolism $2000 \mathbf{8 5}$ 1026-1031.

5 Nestler JE, Barlascini CO, Clore JN \& Blackard WG. Dehydroepiandrosterone reduces serum low density lipoprotein levels and body fat but does not alter insulin sensitivity in normal men. Journal of Clinical Endocrinology and Metabolism 198866 57-61.

6 Villareal DT, Holloszy JO \& Kohrt WM. Effects of DHEA replacement on bone mineral density and body composition in elderly women and men. Clinical Endocrinology 200053 561-568.

7 Gordon G, Newitt J, Shantz L, Weng D \& Talalay P. Inhibition of the conversion of 3T3-L1 fibroblast clones to adipocytes by dehydroepiandrosterone and related anticarcinogenic steroids. Cancer Research 198646 3389-3395.

8 Shantz L, Talalay P \& Gordon G. Mechanism of inhibition of growth of 3T3-L1 fibroblasts and their differentiation to adipocytes by dehydroepiandrosterone and related steroids: role of glucose-6phosphate dehydrogenase. PNAS $1989863852-3856$.

9 Lea-Currie YR, Wen P \& McIntosh MK. Dehydroepiandrosterone reduces proliferation and differentiation of 3T3-L1 preadipocytes. Biochemical and Biophysical Research Communications 1998248 497-504.

10 Matthaei S, Stumvoll M, Kellerer M \& Haring HU. Pathophysiology and pharmacological treatment of insulin resistance. Endocrine Reviews 200021 585-618.

11 Saltiel AR. The molecular and physiological basis of insulin resistance: emerging implications for metabolic and cardiovascular diseases. Journal of Clinical Investigation $2000 \mathbf{1 0 6}$ 163-164.

12 Despres JP. Dyslipidaemia and obesity. Bailliere's Clinical Endocrinology and Metabolism 19948 629-660.

13 Buffington CK, Givens JR \& Kitabchi AE. Opposing actions of dehydroepiandrosterone and testosterone on insulin sensitivity. In vivo and in vitro studies of hyperandrogenic females. Diabetes $199140693-700$.

14 Matsuzawa Y, Funahashi T \& Nakamura T. Molecular mechanism of metabolic syndrome X: contribution of adipocytokines, adipocyte-derived bioactive substances. Annals of the New York Academy of Sciences 1999892 146-154.

15 Arita Y, Kihara S, Ouchi N, Takahashi M, Maeda K, Miyagawa J, Hotta K, Shimomura I, Nakamura T, Miyaoka K, Kuriyama H, Nishida M, Yamashita S, Okubo K, Matsubara K, Muraguchi M, Ohmoto Y, Funahashi T \& Matzuwara Y. Paradoxical decrease of an adipose-specific protein, adiponectin, in obesity. Biochemical and Biophysical Research Communications 1999257 79-83.

16 Garaulet M, Viguerie N, Porubsky S, Klimcakova E, Clement K, Langin D \& Stich V. Adiponectin gene expression and plasma values in obese women during very-low-calorie diet. Relationship with cardiovascular risk factors and insulin resistance. Journal of Clinical Endocrinology and Metabolism $200489756-760$.
17 Combs TP, Berg AH, Obici S, Scherer PE \& Rossetti L. Endogenous glucose production is inhibited by the adipose-derived protein Acrp30. Journal of Clinical Investigation 2001108 1875-1881.

18 Hotta K, Funahashi T, Arita Y, Takahashi M, Matsuda M, Okamoto Y, Iwahashi H, Kuriyama H, Ouchi N, Maeda K, Nishida M, Kihara S, Sakai N, Nakajima T, Hasegawa K, Muraguchi M, Ohmoto Y, Nakamura T, Yamashita S, Hanafusa T \& Matsuzawa Y. Plasma concentrations of a novel, adipose-specific protein, adiponectin, in type 2 diabetic patients. Arteriosclerosis, Trombosis and Vascular Biology 200020 1595-1599.

19 Sociedad Española para el Estudio de la Obesidad (SEEDO). Consenso SEEDO'2000 para la evaluación del sobrepeso y la obesidad y el establecimiento de criterios de intervención terapéutica. (article in Spanish). Medicina Clinica (Barc) 2000 115 587-597.

20 Ascaso JF, Romero P, Real JT, Priego A, Valdecabres C \& Carmena R. Insulin resistance quantification by fasting insulin plasma values and HOMA indexin a non-diabetic population (article in Spanish). Medicina Clinica (Barc) 2001117 530-533.

21 Rodbell M. Metabolism of isolated fat cells. Effects of hormones on glucose metabolism and lipolisis. Journal of Biological Chemistry 1964239 313-319.

22 Livak KJ \& Schmittgen TD. Analysis of relative gene expression data using real-time quantitative PCR and the 2(-Delta Delta $\mathrm{C}(\mathrm{T})$ ) method. Methods 200125 402-408.

23 Sjostrom L, Bjorntorp P \& Vrana J. Cellularity in different region of adipose tissue in young men and women. Metabolism 197221 1143-1153.

24 Fain JN, Madan AK, Hiler MLL, Cheema P \& Bahouth SW. Comparison of the release of adipokines by adipose tissue, adipose tissue matrix, and adipocytes from visceral and subcutaneous abdominal adipose tissues of obese humans. Endocrinology 2004 $1452273-2282$.

25 Arner P. Regional differences in protein production by human adipose tissue. Biochemical Society Transactions 200129 72-75.

26 Wu XD, Hoffstedt J, Deeb W, Singh R, Sedkova N, Zilbering A, Zhu L, Park PK, Arner P \& Goldstein BJ. Depot-specific variation in protein-tyrosine phosphatase activities in human omental and subcutaneous adipose tissue: a potential contribution to differential insulin sensitivity. Journal of Clinical Endocrinology and Metabolism 200186 5973-5980.

27 Yang WS, Chen MH, Lee WJ, Lee KC, Chao CL, Huang KC, Chen CL, Tai TY \& Chuang LM. Adiponectin mRNA levels in the abdominal adipose depots of nondiabetic women. International Journal of Obesity and Related Metabolic Disorders 2003 27 896-900.

28 Lihn AS, Bruun JM, He G, Pedersen SB, Jensen PF \& Richelsen B. Lower expression of adiponectin mRNA in visceral adipose tissue in lean and obese subjects. Molecular and Cellular Endocrinology 2004219 9-15.

29 Fisher FM, McTernan PG, Valsamakis G, Chetty R, Harte AL, Anwar AJ, Starcynski J, Crocker J, Barnett AH, McTernan CL \& Kumar S. Differences in adiponectin protein expression: effect of fat depots and type 2 diabetes status. Hormone and Metabolic Research 200234 650-654.

30 Pischon T, Girman CJ, Rifai N, Hotamisligil GS \& Rimm EB. Association between dietary factors and plasma adiponectin concentrations in men. American Journal of Clinical Nutrition $200581780-786$.

31 Ruano M, Silvestre V, Castro R, Garcia-Lescun MCG, Aguirregoicoa E, Marco A, Rodriguez A \& Garcia-Blanch G. HOMA, QUICKI and MFfm to measure insulin resistance in morbid obesity. Obesity Surgery 200616 549-553.

32 Yamaguchi Y, Tanaka S, Yamakawa T, Kimura M, Ukawa K, Yamada Y, Ishihara M \& Sekihara H. Reduced serum dehydroepiandrosterone levels in diabetic patients with hyperinsulinaemia. Clinical Endocrinology 199849 377-383.

33 Herrington DM, Gordon GB, Achuff SC, Trejo JF, Weissman HF, Kwiterovich PO, Jr \& Pearson TA. Plasma dehydroepiandrosterone 
and dehydroepiandrosterone sulfate in patients undergoing diagnostic coronary angiography. Journal of the American College of Cardiology $199016862-870$.

34 Karbowska J \& Kochan Z. Effect of DHEA on endocrine functions of adipose tissue, the involvement of PPAR gamma. Biochemical Pharmacology 200570 249-257.

35 Cnop M, Landchild MJ, Vidal J, Havel PJ, Knowles NG, Carr DR, Wang F, Hull RL, Boyko EJ, Retzlaff BM, Walden CE, Knopp RH \& Khan SE. The concurrent accumulation of intra-abdominal and subcutaneous fat explains the association between insulin resistance and plasma leptin concentrations: distinct metabolic effects of two fat compartments. Diabetes 200251 1005-1015.

36 Liu D \& Dillon JS. Dehydroepiandrosterone activates endothelial cell nitric-oxide synthase by a specific plasma membrane receptor coupled to Galpha(i2,3). Journal of Biological Chemistry 2002277 21379-21388.

$37 \mathrm{Xu} \mathrm{A,} \mathrm{Chan} \mathrm{KW,} \mathrm{Hoo} \mathrm{RL,} \mathrm{Wang} \mathrm{Y,} \mathrm{Tan} \mathrm{KC,} \mathrm{Zhang} \mathrm{J,} \mathrm{Chen} \mathrm{B,}$ Lam MC, Tse C, Cooper GL \& Lam KS. Testosterone selectively reduces the high molecular weight form of adiponectin by inhibiting its secretion from adipocytes. Journal of Biological Chemistry $2005 \mathbf{2 8 0} 18073-18080$.
38 Zhou YC \& Waxman DJ. Activation of peroxisome proliferatoractivated receptors by chlorinated hydrocarbons and endogenous steroids. Environmental Health Perspectives 1998106 (Suppl 4) 983-988.

39 Iwaki M, Matsuda M, Maeda N, Funahashi T, Matsuzawa Y, Makishima M \& Shimomoura I. Induction of adiponectin, a fatderived antidiabetic and antiatherogenic factor, by nuclear receptors. Diabetes 200352 1655-1663.

40 Tonelli J, Li W, Kishore P, Pajvani UB, Kwon E, Weaver C, Scherer PE \& Hawkins M. Mechanisms of early insulin-sensitizing effects of thiazolidinediones in type 2 diabetes. Diabetes 200453 1621-1629.

41 Chandran M, Phillips SA, Ciaraldi T \& Henry RR. Adiponectin: more than just another fat cell hormone? Diabetes Care 200326 2442-2450.

Received 24 April 2006

Accepted 17 July 2006 